\title{
Effect of fertigation with potassium and nitrogen on gas exchange and biomass accumulation in eggplant ${ }^{1}$
}

\author{
Álvaro Henrique Cândido de Souza², Roberto Rezende², \\ Marcelo Zolin Lorenzoni² ${ }^{2}$ Fernando André Silva Santos ${ }^{2}$, André Maller ${ }^{2}$
}

\section{ABSTRACT}

Adequate crop fertilization is one of the challenges for agriculture. Measuring gas exchange and biomass accumulation may be used to adjust crop management. The effect of fertigation with potassium $\left(0 \mathrm{~kg} \mathrm{ha}^{-1}, 54 \mathrm{~kg} \mathrm{ha}^{-1}\right.$, $108 \mathrm{~kg} \mathrm{ha}^{-1}$ and $\left.216 \mathrm{~kg} \mathrm{ha}^{-1}\right)$ and nitrogen $\left(0 \mathrm{~kg} \mathrm{ha}^{-1}, 67 \mathrm{~kg} \mathrm{ha}^{-1}\right.$, $134 \mathrm{~kg} \mathrm{ha}^{-1}$ and $\left.268 \mathrm{~kg} \mathrm{ha}^{-1}\right)$ on gas exchange and biomass accumulation in eggplant was assessed under greenhouse conditions. The net photosynthesis, stomatal conductance, transpiration, internal $\mathrm{CO}_{2}$ concentration, instantaneous carboxylation efficiency, water-use efficiency and total dry weight were evaluated. With the exception of $\mathrm{K}$ for water-use efficiency and $\mathrm{N}$ for internal $\mathrm{CO}_{2}$ concentration, all the other gas exchange parameters were significantly affected by the $\mathrm{K}$ and $\mathrm{N}$ doses. There was an interaction between $\mathrm{N}$ and $\mathrm{K}$ doses for net photosynthesis, stomatal conductance, transpiration and instantaneous carboxylation efficiency. The highest values for net photosynthesis, stomatal conductance, transpiration rate, carboxylation instantaneous efficiency and total dry weight were found in the range of $125-185 \mathrm{~kg} \mathrm{ha}^{-1}$ of $\mathrm{K}$ and $215-268 \mathrm{~kg} \mathrm{ha}^{-1}$ of $\mathrm{N}$.

KEYWORDS: Solanum Melongena L.; photosynthesis; mineral nutrition; water-use efficiency.

\section{INTRODUCTION}

Adequate crop fertilization is one of the most important factors for improving yield (Bhuvaneswari et al. 2014). Nitrogen (N) is an element highly demanded by vegetables and presents a low availability, mainly in tropical soils (Pimentel 1998). $\mathrm{N}$ is important for the biosynthesis of amino acids which form proteins. In addition, it is necessary for the synthesis of chlorophyll and photosynthesis (Lopes 1998, Bhuvaneswari et al. 2014).

$\mathrm{N}$ is strongly related with net photosynthesis rate and, consequently, with carbon absorption and vegetable growth, varying between plant species and

\section{RESUMO}

Efeito da fertirrigação com potássio e nitrogênio nas trocas gasosas e acúmulo de biomassa em berinjela

A fertilização adequada das culturas é um dos desafios na agricultura. Medir as trocas gasosas e o acúmulo de biomassa é indicado para encontrar condições mais favoráveis para as plantas. Avaliou-se o efeito da fertirrigação com potássio $\left(0 \mathrm{~kg} \mathrm{ha}^{-1}\right.$, $54 \mathrm{~kg} \mathrm{ha}^{-1}, 108 \mathrm{~kg} \mathrm{ha}^{-1}$ e $\left.216 \mathrm{~kg} \mathrm{ha}^{-1}\right)$ e nitrogênio $\left(0 \mathrm{~kg} \mathrm{ha}^{-1}\right.$, $67 \mathrm{~kg} \mathrm{ha}^{-1}, 134 \mathrm{~kg} \mathrm{ha}^{-1} \mathrm{e} 268 \mathrm{~kg} \mathrm{ha}^{-1}$ ) nas trocas gasosas e acúmulo de biomassa em berinjela, em estufa. A fotossíntese líquida, condutância estomática, transpiração, concentração interna de $\mathrm{CO}_{2}$, eficiência de carboxilação instantânea, eficiência do uso da água e matéria seca total foram avaliadas. Com exceção do K para a eficiência do uso da água e $\mathrm{N}$ para a concentração interna de $\mathrm{CO}_{2}$, todos os outros parâmetros de trocas gasosas apresentaram diferenças significativas para as doses de K e N. Houve interação entre as doses de N e K para fotossíntese, condutância estomática, transpiração e eficiência instantânea de carboxilação. Os maiores valores para fotossíntese líquida, condutância estomática, transpiração, eficiência de carboxilação instantânea e matéria seca total foram encontrados na faixa de $125-185 \mathrm{~kg} \mathrm{ha}^{-1}$ de $\mathrm{K}$ e $215-268 \mathrm{~kg} \mathrm{ha}^{-1}$ de N.

PALAVRAS-CHAVE: Solanum Melongena L.; fotossíntese; nutrição mineral; eficiência do uso da água.

functional groups (Felsemburgh 2006). Aminifard et al. (2010) observed differences in eggplant leaf chlorophyll content under different $\mathrm{N}$ fertilization.

Potassium (K) is the nutrient most required by vegetables (Faquin \& Andrade 2004), playing an important role in several vital biological processes, such as enzymatic activation, respiration, photosynthesis and improvement in water balance (Lopes 1998, Prazeres et al. 2015). Hochmuth et al. (1993) and Fawzy et al. (2007) reported that K leaf concentration is influenced by $\mathrm{K}$ doses on eggplant.

In spite of many studies about the effect of fertilization with $\mathrm{N}$ and $\mathrm{K}$ in eggplant (Hochmuch et al. 1993, Fawzy et al. 2007, Aminifard et al. 2010, 
Souza et al. 2017), the physiological responses of eggplants under $\mathrm{K}$ and $\mathrm{N}$ doses have not been well documented. The photosynthesis, transpiration, stomatal conductance and internal $\mathrm{CO}_{2}$ concentration may be used to diagnose physiological alterations in plants submitted to adverse conditions (Andrade Junior et al. 2011).

One of the challenges in fertilization is to balance the levels of $\mathrm{N}$ and $\mathrm{K}$ within the plant (Lopes 1998). When used without agronomic criteria, unbalanced fertilization may reduce the yield and net profit, as a consequence of the disparities between the nutrients demand by crops and their availability in the soil. Thus, this study aimed to evaluate the effect of fertigation with $\mathrm{K}$ and $\mathrm{N}$ on gas exchange and biomass accumulation, in eggplant cultivated under greenhouse conditions.

\section{MATERIAL AND METHODS}

Eggplant ('Ciça' cultivar) was grown in a greenhouse (20 $\mathrm{m}$ long, $7 \mathrm{~m}$ wide and $3 \mathrm{~m}$ high) with an arched cover coated with low-density polyethylene film and laterals protected with anti-aphid screen, at the Universidade Estadual de Maringá, in Maringá,

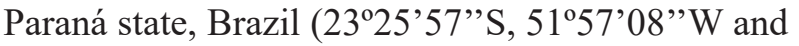
altitude of $542 \mathrm{~m}$ ), from February to August 2015.

The local climate is characterized as humid mesothermal (Cfa), according to the Köppen classification (Peel et al. 2007). The weather data for the experimental period were obtained from a meteorological station installed inside the greenhouse.

The average value for relative air humidity, minimum and maximum temperature recorded inside the greenhouse were $62.5 \%, 6.4{ }^{\circ} \mathrm{C}$ and $39.4{ }^{\circ} \mathrm{C}$, respectively. For eggplant cultivation, the ideal temperature is $20-35^{\circ} \mathrm{C}$ (Ribeiro 2007). During the cycle, temperatures lower and higher than those indicated for the crop were registered.

The experimental design was completely randomized, in a factorial scheme with four doses of $\mathrm{N}\left(0 \mathrm{~kg} \mathrm{ha}^{-1}, 67 \mathrm{~kg} \mathrm{ha}^{-1}, 134 \mathrm{~kg} \mathrm{ha}^{-1}\right.$ and $\left.268 \mathrm{~kg} \mathrm{ha}^{-1}\right)$ and four doses of $\mathrm{K}\left(0 \mathrm{~kg} \mathrm{ha}^{-1}\right.$, $54 \mathrm{~kg} \mathrm{ha}^{-1}, 108 \mathrm{~kg} \mathrm{ha}^{-1}$ and $216 \mathrm{~kg} \mathrm{ha}^{-1}$ ), with four replicates, totaling 64 experimental units. The unit was represented by a pot with volumetric capacity of $25 \mathrm{~L}$.

Eggplant seeds were sowed in 64 cell trays filled with commercial potting mix based on pinus bark (Mecplant ${ }^{\circledR}$, Telemaco Borba, Paraná). One seedling was transplanted to each pot when the seedlings had five to six true leaves.

Pots were filled with soil classified as Dystrophic Red Latosol (Oxisol) (Embrapa 2013), with sandy texture and the following physical and chemical characteristics: sand $=780 \mathrm{~g} \mathrm{~kg}^{-1}$; silt $=30 \mathrm{~g} \mathrm{~kg}^{-1}$; clay $=190 \mathrm{~g} \mathrm{~kg}^{-1} ; \mathrm{P}=8.63 \mathrm{mg} \mathrm{dm}^{-3}$; $\mathrm{Na}^{+}=2.10 \mathrm{mg} \mathrm{dm}{ }^{-3} ; \mathrm{K}^{+}=0.07 \mathrm{cmol}_{\mathrm{c}} \mathrm{dm}^{-3} ; \mathrm{Ca}^{+2}=$ $1.56 \mathrm{cmol}_{\mathrm{c}} \mathrm{dm}^{-3} ; \mathrm{Mg}^{+2}=0.38 \mathrm{cmol}_{\mathrm{c}} \mathrm{dm}^{-3} ; \mathrm{Al}^{+3}=$ $0.7 \mathrm{cmol}_{\mathrm{c}} \mathrm{dm}^{-3} ; \mathrm{H}^{+}=2.48 \mathrm{cmol}_{\mathrm{c}} \mathrm{dm}^{-3}$. Liming was performed at 60 days before the transplantation (DBT) and basal fertilization at $20 \mathrm{DBT}$, with $32 \mathrm{~g}$ of dolomitic limestone, $30 \mathrm{~g}$ of $\mathrm{P}_{2} \mathrm{O}_{5}$ (single superphosphate), $500 \mathrm{~g}$ of commercial substrate of pinus bark $\left(\right.$ Mecplant $\left.^{\mathbb{Q}}\right)$ organic compost and $10 \mathrm{~g}$ of $\mathrm{K}_{2} \mathrm{O}$ (potassium chloride) (106 $\mathrm{kg} \mathrm{ha}^{-1}$ ) per pot (Trani 2014).

The experimental area consisted of five rows spaced $1.2 \mathrm{~m}$ and pots placed $0.8 \mathrm{~m}$ apart. $\mathrm{N}$ and $\mathrm{K}$ doses were applied weekly, according to the absorption curve of nutrients for the eggplant crop (Trani et al. 2011). Fertilizers were applied at the $1-2$ nd $(3.45 \%$ of the total dose), 3-4th $(5.17 \%)$, 5-10th (8.62\%) and 11-16th (5.17\%) week.

For irrigation management, the $-15 \mathrm{kPa}$ critical tension was considered (Bilibio et al. 2010). This water potential was equivalent to a gravimetric water content of $0.08 \mathrm{~kg} \mathrm{~kg}^{-1}$. At the maximum soil holding capacity, the gravimetric water content was $0.2 \mathrm{~kg} \mathrm{~kg}^{-1}$ (Casaroli \& Lier 2008).

Gas exchange was measured in the morning (7-11 a.m.) on the third leaf from the plant apex, at 98 days after transplantation (DAT), using an infrared gas analyzer IRGA (LCpro+, ADC BioScientific Ltda, UK), with photosynthetic photon density of $600 \mu \mathrm{mol} \mathrm{m} \mathrm{m}^{-2} \mathrm{~s}^{-1}$. The infrared gas analyzer was also used for determining the net photosynthesis, stomatal conductance, transpiration rate and internal $\mathrm{CO}_{2}$ concentration. The ratio between net photosynthesis and internal concentration of $\mathrm{CO}_{2}$ allowed to calculate the carboxylation instantaneous efficiency, while the ratio between the net photosynthesis and transpiration rate allowed to determine the water-use efficiency.

At the end of the experiment (137 DAT), plants were dissected in roots, stems and leaves, and dried in a forced-air oven at $65^{\circ} \mathrm{C}$, to reach a constant dry weight. The total dry weight was also determined.

The Pearson correlation coefficient was used to correlate data of gas exchange (net photosynthesis, stomatal conductance and transpiration rate) with 
yield. The values for eggplant yield were previously published by Souza et al. (2017).

Analysis of variance was used to evaluate the significance of the differences among treatments. When the interaction between $\mathrm{N}$ and $\mathrm{K}$ was significant, a multiple regression analysis was performed using the Backward Euler method, and the Student's t-test was used to analyze the significance of the regression coefficients $(\mathrm{p}<0.05)$. Otherwise, regression analysis was performed individually for the significant treatments ( $\mathrm{N}$ and/or $\mathrm{K}$ doses).

\section{RESULTS AND DISCUSSION}

Based on the analysis of variance (Table 1), there was an interaction between $\mathrm{N}$ and $\mathrm{K}$ doses for net photosynthesis, stomatal conductance, transpiration rate and carboxylation instantaneous efficiency $(\mathrm{p}<0.05)$. There was no interaction for internal $\mathrm{CO}_{2}$ concentration, water-use efficiency and total dry weight $(\mathrm{p}>0.05)$. The individual effect of $\mathrm{K}$ did not influence the water-use efficiency, while the individual effect of $\mathrm{N}$ did not influence the internal $\mathrm{CO}_{2}$ concentration (Table 1). All other variables were influenced by the individual effect of $\mathrm{K}$ and $\mathrm{N}$.

The $\mathrm{K}$ application caused a quadratic tendency on net photosynthesis (Figure 1a). The highest net photosynthesis $\left(17.3 \mu \mathrm{mol} \mathrm{m}^{-2} \mathrm{~s}^{-1}\right.$ of $\left.\mathrm{CO}_{2}\right)$ was reached with $175 \mathrm{~kg} \mathrm{ha}^{-1}$ of $\mathrm{K}$ and the highest $\mathrm{N}$ dose $\left(268 \mathrm{~kg} \mathrm{ha}^{-1}\right.$ ). Higher doses of K (above $175 \mathrm{~kg} \mathrm{ha}^{-1}$ ) reduce the net photosynthesis, possibly because of the reduction in the soil osmotic potential, which is not tolerated by the crop (Andrade Junior et al. 2011).

There was a low increase on net photosynthesis with increasing $\mathrm{K}$ under low $\mathrm{N}$ doses, probably due to the process of photochemical conversion to energy, which requires an appropriate amount of $\mathrm{N}$, as well as other nutrients that are incorporated into structural components, enzymes and other metabolic components (Felsemburgh 2006). Cruz et al. (2007) showed that the photosynthetic rate had a positive and significant correlation with the addition of $\mathrm{N}$ on papaya, evidencing the essentiality of this nutrient.

Nitrogen is the main component of RuBPCase, which is a protein involved in photosynthesis (Seemann et al. 1987). The chlorophyll content and RuPBcase depend linearly on total leaf N (Evans 1983). Usually, a high content of $\mathrm{N}$ is associated with high rates of maximum photosynthesis (Felsemburgh 2006).

The evaluated doses caused a similar effect on stomatal conductance, if compared to net photosynthesis. The stomatal conductance may limit photosynthesis through the restriction of the $\mathrm{CO}_{2}$ available in the leaf tissues (Silva et al. 2015). This hypothesis is supported by the high correlation between net photosynthesis and stomatal conductance $(\mathrm{r}=0.96)$.

One of the main reasons for the stomatal conductance reduction with higher $\mathrm{K}$ doses is probably saline stress (excessive application), because $\mathrm{K}$ has a high saline index (Prazeres et al. 2015). Excessive $\mathrm{K}$ in the leaf may cause stomatal closing, thus reducing the normal flow of $\mathrm{CO}_{2}$ for carboxylation (Xu et al. 1994). In Hordeum vulgare, the maximum photosynthetic $\mathrm{CO}_{2}$ assimilation was reduced under saline stress induced with $\mathrm{NaCl}$ doses (Innocenti et al. 2009).

Nitrogen doses induced a linear response in stomatal conductance; therefore, it is possible to infer that a restriction in the $\mathrm{CO}_{2}$ input and Calvin cycle has not occurred. Evans (1983) observed a quadratic effect of $\mathrm{N}$ doses on stomatal conductance, which could have

Table 1. Analysis of variance for net photosynthesis (A), stomatal conductance $(g \mathrm{~s})$, transpiration rate (E), internal $\mathrm{CO}_{2}$ concentration (Ci), carboxylation instantaneous efficiency (CiE), water-use efficiency (WUE) and total dry weight (TDW).

\begin{tabular}{|c|c|c|c|c|c|}
\hline \multirow{3}{*}{ Variable } & \multicolumn{3}{|c|}{ Variation source } & \multirow{3}{*}{ CV (\%) } & \multirow{3}{*}{ Average } \\
\hline & $\mathrm{K}$ & $\mathrm{N}$ & $\mathrm{N} \times \mathrm{K}$ & & \\
\hline & & F value & & & \\
\hline $\mathrm{A}$ & $31.105^{* *}$ & $61.508^{* *}$ & $16.132 * *$ & 20.51 & 8.76 \\
\hline gs & $23.866^{* *}$ & $50.880 * *$ & $12.463 * *$ & 26.02 & 0.12 \\
\hline $\mathrm{E}$ & $18.683 * *$ & $18.131 * *$ & $7.803 * *$ & 24.26 & 1.57 \\
\hline $\mathrm{Ci}$ & $3.180^{*}$ & $1.900^{\mathrm{ns}}$ & $0.753^{\mathrm{ns}}$ & 10.58 & 226.91 \\
\hline $\mathrm{CiE}$ & $25.037 * *$ & $51.951 * *$ & $12.198 * *$ & 22.96 & 0.04 \\
\hline WUE & $1.440^{\mathrm{ns}}$ & $7.27 * *$ & $1.982^{\mathrm{ns}}$ & 25.02 & 5.41 \\
\hline TDW & $3.37 *$ & $43.676^{* *}$ & $1.913^{\mathrm{ns}}$ & 24.12 & 265.53 \\
\hline
\end{tabular}

${ }_{\mathrm{ns}}$ Non-significant at $0.05 ; *$ significant at $0.05 ; * *$ significant at 0.01 . 
happened due to two possible causes: either some of the RuBPCase is inactive or there is a finite wall and liquid-phase conductance to $\mathrm{CO}_{2}$ diffusion.

It was observed that the net photosynthesis and stomatal conductance may be limited by a low availability of $\mathrm{N}$ or $\mathrm{K}$, according to the Law of the Minimum (Liebig 1840).

For the transpiration rate, the analysis of variance showed a significant interaction between the $\mathrm{N}$ and $\mathrm{K}$ doses (Table 1). The $\mathrm{K}$ effect on the transpiration rate was explained with a quadratic model, where the highest transpiration rate $\left(2.74 \mathrm{mmol} \mathrm{m}^{-2} \mathrm{~s}^{-1}\right.$ of $\mathrm{H}_{2} \mathrm{O}$ ) occurred at $185 \mathrm{~kg} \mathrm{ha}^{-1}$ of $\mathrm{K}$, with the highest $\mathrm{N}$ dose $\left(268 \mathrm{~kg} \mathrm{ha}^{-1}\right)$ (Figure 1c).

Excessive applications of potassium chloride may increase the soil electric conductivity, and consequently reduce gas exchange. Bosco et al. (2009) studied the effect of electric conductivity in eggplant crop and verified a reduction in the photosynthesis, transpiration rate and stomatal conductance, with the application of sodium chloride, because of salinity. Salinity stress may lead to ion imbalance and hyper-osmotic stress (Innocenti et al. 2009). Ma et al. (2013) verified a plateau effect on gas exchange in wheat under $\mathrm{K}$ doses and attributed this effect to luxury fertilization, but they applied lower doses than in this study.

The $\mathrm{N}$ application caused a low increase on the transpiration rate under low $\mathrm{K}$ doses. Hafsi et al. (2016) verified a reduction on net photosynthesis, stomatal conductance to water vapor and intercellular
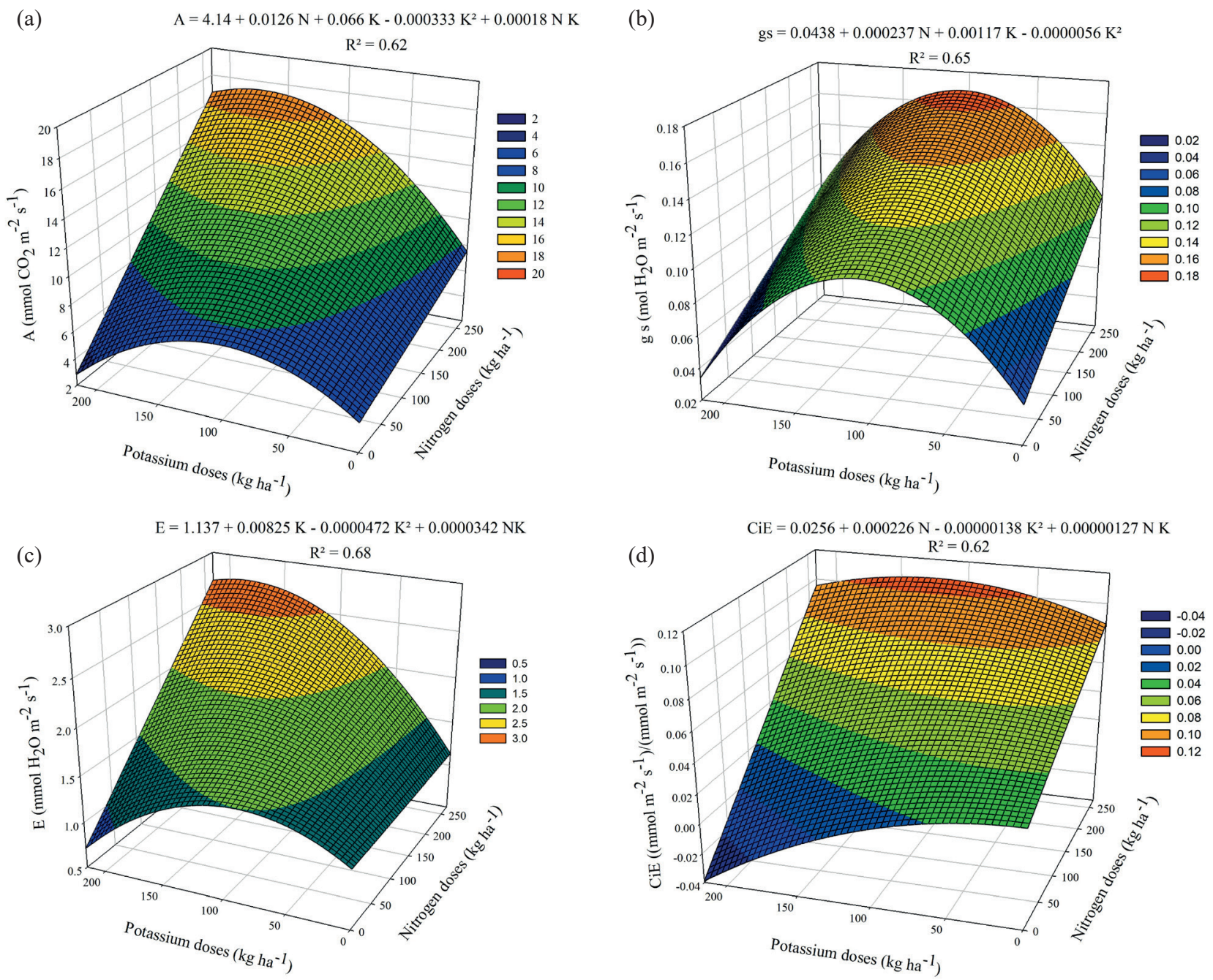

Figure 1. Net photosynthesis (a), stomatal conductance (b), transpiration (c) and carboxylation instantaneous efficiency (d) of eggplant, as a function of potassium $\left(0 \mathrm{~kg} \mathrm{ha}^{-1}, 54 \mathrm{~kg} \mathrm{ha}^{-1}, 108 \mathrm{~kg} \mathrm{ha}^{-1}\right.$ and $\left.216 \mathrm{~kg} \mathrm{ha}^{-1}\right)$ and nitrogen $\left(0 \mathrm{~kg} \mathrm{ha}^{-1}, 67 \mathrm{~kg} \mathrm{ha}^{-1}\right.$, $134 \mathrm{~kg} \mathrm{ha}^{-1}$ and $\left.268 \mathrm{~kg} \mathrm{ha}^{-1}\right)$ doses. 
$\mathrm{CO}_{2}$ concentration under $\mathrm{K}$ deficiency, in Sulla carnosa plants.

There was a significant interaction between the $\mathrm{N}$ and $\mathrm{K}$ doses for carboxylation instantaneous efficiency $(\mathrm{p}<0.05)$. The $\mathrm{K}$ dose of $125 \mathrm{~kg} \mathrm{ha}^{-1}$ promoted the highest carboxylation instantaneous efficiency $\left(0.107 \mu \mathrm{mol} \mathrm{m}^{-2} \mathrm{~s}^{-1} / \mu \mathrm{mol} \mathrm{m}^{-2} \mathrm{~s}^{-1}\right)$ (Figure 1d). The $\mathrm{N}$ application increased the carboxylation instantaneous efficiency; however, there was a deleterious effect of $\mathrm{N}$ when $\mathrm{K}$ was not applied to the eggplant (Figure 1d). $\mathrm{N}$ deficiencies decrease the protein synthesis in chlorophylls, restricting the production of the ATP and NADPH used in the $\mathrm{CO}_{2}$ fixation process. The carboxylation instantaneous efficiency also depends on the availability of $\mathrm{CO}_{2}$ in the leaf mesophyll, amount of light, temperature and enzymatic activity.

Melo et al. (2009) obtained a high correlation between photosynthesis rate and internal carbon concentration, evaluating fertigation in banana under $\mathrm{K}$ and $\mathrm{N}$ doses. Besides, with $\mathrm{N}$ application, there was an increase on the carboxylation instantaneous efficiency, in comparison to the plants with no application. However, under higher $\mathrm{N}$ doses, the carboxylation instantaneous efficiency was reduced, possibly due to increases in the Rubisco oxygenase activity, in detriment of carboxylase. This causes a reduction in the carbon assimilation rate, even under a high $\mathrm{N}$ availability (Melo et al. 2009).

The total dry weight was best fitted to the quadratic model, where the highest values obtained were $292.7 \mathrm{~g} \mathrm{plant}^{-1}$ and $367.8 \mathrm{~g} \mathrm{plant}^{-1}$, with $145 \mathrm{~kg} \mathrm{ha}^{-1}$ of K (Figure 2a) and $215 \mathrm{~kg} \mathrm{ha}^{-1}$ of N, respectively (Figure 2b). These values represent an increment of $28.1 \%$ and $190.8 \%$, respectively, in comparison to the control with no fertilization. $\mathrm{N}$ is one of the essential macronutrients required for growth (Bhuvaneswari et al. 2014). K, on the other hand, is not used in organic molecules and, therefore, has no structural function (Faquin \& Andrade 2004).

Prazeres et al. (2015) noticed a quadratic effect of $\mathrm{K}$ doses on total dry weight, resulting
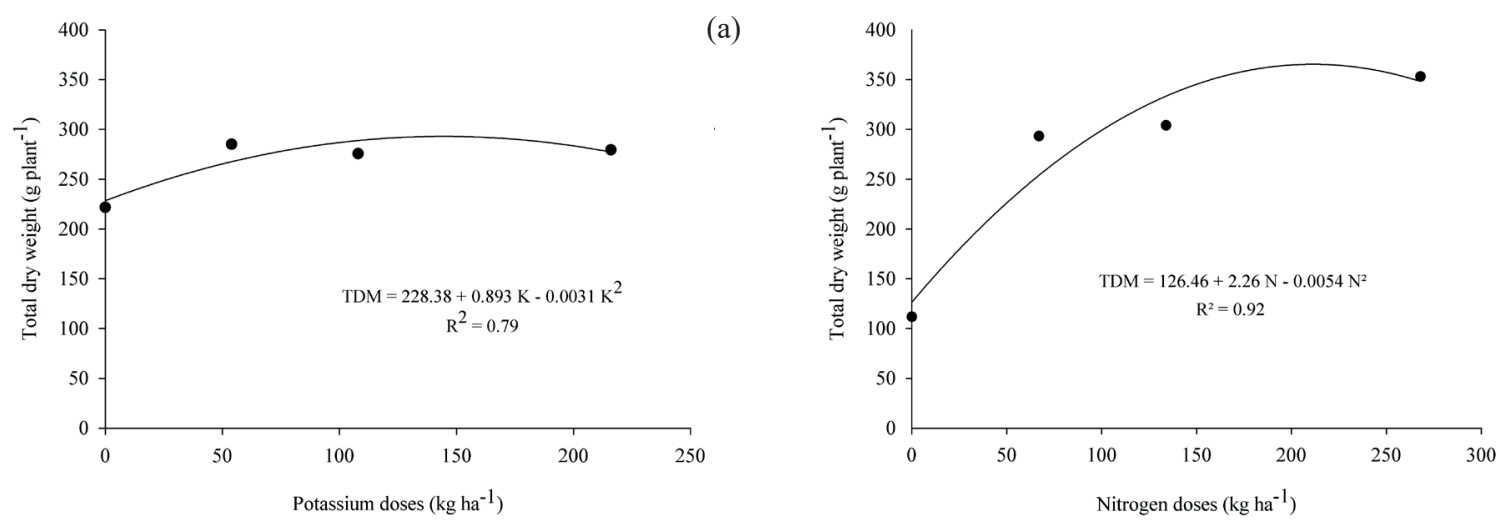

(b)

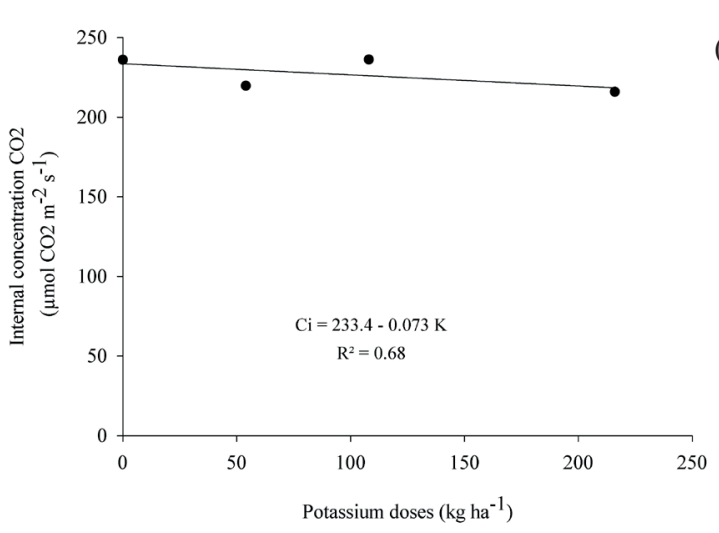

(c)

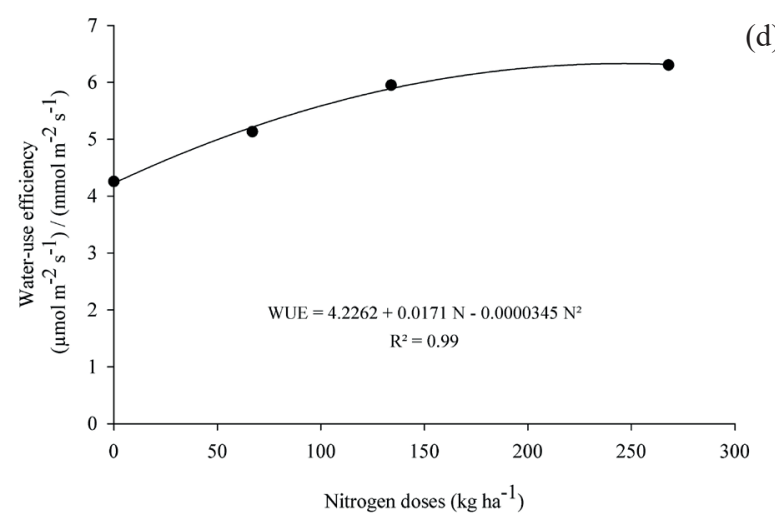

(d)

Figure 2. Total dry weight of eggplant, as a function of potassium (a) $\left(0 \mathrm{~kg} \mathrm{ha}^{-1}, 54 \mathrm{~kg} \mathrm{ha}^{-1}, 108 \mathrm{~kg} \mathrm{ha}^{-1}\right.$ and $\left.216 \mathrm{~kg} \mathrm{ha}^{-1}\right)$ and nitrogen (b) $\left(0 \mathrm{~kg} \mathrm{ha}^{-1}, 67 \mathrm{~kg} \mathrm{ha}^{-1}, 134 \mathrm{~kg} \mathrm{ha}^{-1}\right.$ and $\left.268 \mathrm{~kg} \mathrm{ha}^{-1}\right)$ doses; internal $\mathrm{CO}_{2}$ concentration, as a function of potassium (c); and water-use efficiency, as a function of nitrogen doses (d). 
in an increase of $19 \%$, in comparison to low $\mathrm{K}$ doses in watermelon. Hafsi et al. (2011) observed that $\mathrm{K}$ deficiency resulted in a reduction of the biomass production in shoots and roots of Hordeum maritimum. Vegetative growth decreased with $\mathrm{K}$ deficiency, what might be due to the combined effect of decreased leaf surface area, shoot height and number of leaves (Hafsi et al. 2016).

The result is close to that by Lorenzoni et al. (2016), who noted the positive impacts of $\mathrm{N}$ on the total dry weight of bell pepper, with doses of 162$194 \mathrm{~kg} \mathrm{ha}^{-1}$ of N. Nitrogen deficiency leads plants to senesce earlier than plants with high $\mathrm{N}$ doses (Evans 1983). The range of tested doses allowed the identification of the $\mathrm{N}$ rate that maximizes the eggplant biomass accumulation.

There was only a small effect of $\mathrm{K}$ doses, causing a decrease in the internal $\mathrm{CO}_{2}$ concentration (Figure $2 \mathrm{c}$ ). $\mathrm{K}$ is involved in stomata opening and closing, therefore regulating the diffusivity of $\mathrm{CO}_{2}$ in the mesophyll cells. As such, K may interfere in the concentration of carbon in the sub stomatal camera (Faquin \& Andrade 2004). Similar results were observed by Bosco et al. (2009), when applying $\mathrm{NaCl}$ in eggplant, what induced a linear reduction on the internal $\mathrm{CO}_{2}$ concentration.

For the water-use efficiency, the analysis of variance just showed a significant effect of $\mathrm{N}$ $(\mathrm{p}<0.01)$ (Table 1), with the highest water-use efficiency $\left(6.34 \mu \mathrm{mol} \mathrm{m}{ }^{-2} \mathrm{~s}^{-1} / \mu \mathrm{mol} \mathrm{m} \mathrm{m}^{-2} \mathrm{~s}^{-1}\right)$ occurring at $250 \mathrm{~kg} \mathrm{ha}^{-1}$ of N (Figure 2d).

The $\mathrm{N}$ doses that maximized the water-use efficiency and total dry weight $\left(250 \mathrm{~kg} \mathrm{ha}^{-1}\right.$ and $215 \mathrm{~kg} \mathrm{ha}^{-1}$, respectively) were close, indicating that the total dry weight (carbon isotope) is a useful proxy of water-use efficiency (Ripullone et al. 2004).

Our results indicate a balance among the variables net photosynthesis, stomatal conductance and transpiration rate in eggplant, pointing out that $\mathrm{N}$ fertilization and, therefore, water-use efficiency, would be a good indicator for other variables. They also indicate that the $\mathrm{N}$ supply did not cause limitations on the physiologic process up to the near maximum dose. Water-use efficiency data may still be explained by genetic factors, due to existent variations for other variables, such as photosynthesis (Taiz \& Zeiger 2013).

C3 metabolism plants require a high stomatal conductance (transpiration) for maintaining high photosynthetic rates (Kerbauy 2008). When the water-use efficiency was evaluated in other crops, similar results were obtained for $\mathrm{N}$ application, if compared to eggplant. Using a fertilizer solution, Ripullone et al. (2004) applied $\mathrm{N}$ in low, medium and high amounts on two forest species seedlings, and concluded that the high $\mathrm{N}$ supply increased the biomass production and water-use efficiency. The water-use efficiency was influenced by the positive effect of $\mathrm{N}$ on the net photosynthesis rates, since stomatal conductance and transpiration were not affected by $\mathrm{N}$ application.

The correlation between gas exchange (net photosynthesis, stomatal conductance and transpiration rate) and yield, using data from all treatments, showed a low and non-significant value for the Pearson correlation coefficient. However, this coefficient was best reached when splitting the data by levels $(\mathrm{N} / \mathrm{K} 1 ; \mathrm{N} / \mathrm{K} 2 ; \mathrm{N} / \mathrm{K} 3 ; \mathrm{N} / \mathrm{K} 4$; $\mathrm{K} / \mathrm{N} 1 ; \mathrm{K} / \mathrm{N} 2 ; \mathrm{K} / \mathrm{N} 3$; and $\mathrm{K} / \mathrm{N} 4$, where $\mathrm{N}$ and $\mathrm{K}$ are, respectively, all tested doses, and $\mathrm{N}_{\mathrm{i}}$ or $\mathrm{K}_{\mathrm{i}}$ a specific tested dose).

The data obtained from the Pearson correlation coefficient between yield and gas exchange (Table 2) showed a higher correlation for fertigation with $\mathrm{N}$ than with $\mathrm{K}$ doses, considering the doses applied. Yield could be more correlated, as a result of gas exchange at the dose N3 (134 kg ha-1 of N), because different $\mathrm{K}$ doses were applied at N1, N2 and N4, and the correlation coefficient was low.

Without $\mathrm{K}$ fertigation $\left(0 \mathrm{~kg} \mathrm{ha}^{-1}\right)$, the high yield response was more related to the lowest transpiration $(-57 \%)$, meaning that, under $\mathrm{K}$ deficiency, it is important to use reduced transpiration rates.

Table 2. Pearson correlation coefficient between yield and gas exchange variables [net photosynthesis (A), stomatal conductance $(g \mathrm{~s})$ and transpiration rate $(\mathrm{E})]$.

\begin{tabular}{|c|c|c|c|c|}
\hline \multicolumn{5}{|c|}{ Pearson correlation coefficient } \\
\hline & & $\mathrm{A}$ & gs & $\mathrm{E}$ \\
\hline \multirow{4}{*}{$\mathrm{N}$} & K1 & $-0.21^{\mathrm{ns}}$ & $-0.22^{\text {ns }}$ & $-0.57^{*}$ \\
\hline & $\mathrm{K} 2$ & $0.69 * *$ & $0.74 * *$ & $0.65 * *$ \\
\hline & $\mathrm{K} 3$ & $0.56^{*}$ & $0.49 *$ & $0.41^{\mathrm{ns}}$ \\
\hline & $\mathrm{K} 4$ & $0.74 * *$ & $0.70 * *$ & $0.71 * *$ \\
\hline \multirow{4}{*}{ K } & N1 & $-0.38^{\mathrm{ns}}$ & $-0.42^{\mathrm{ns}}$ & $-0.29^{\mathrm{ns}}$ \\
\hline & $\mathrm{N} 2$ & $0.13^{\mathrm{ns}}$ & $0.24^{\mathrm{ns}}$ & $-0.29^{\text {ns }}$ \\
\hline & N3 & $0.59 * *$ & $0.55^{*}$ & $0.64 * *$ \\
\hline & N4 & $-0.35^{\mathrm{ns}}$ & $-0.41^{\mathrm{ns}}$ & $-0.21^{\mathrm{ns}}$ \\
\hline & nents & $0.41^{\mathrm{ns}}$ & $0.41^{\mathrm{ns}}$ & $0.28^{\mathrm{ns}}$ \\
\hline
\end{tabular}

${ }^{\text {ns }}$ Non-significant at $0.05 ; *$ significant at $0.05 ; * *$ significant at 0.01 . Potassium doses: $\mathrm{K} 1=0 \mathrm{~kg} \mathrm{ha}^{-1} ; \mathrm{K} 2=54 \mathrm{~kg} \mathrm{ha}^{-1} ; \mathrm{K} 3=108 \mathrm{~kg} \mathrm{ha}^{-1} ; \mathrm{K} 4=216 \mathrm{~kg} \mathrm{ha}^{-1}$. Nitrogen doses: $\mathrm{N} 1=0 \mathrm{~kg} \mathrm{ha}^{-1} ; \mathrm{N} 2=67 \mathrm{~kg} \mathrm{ha}^{-1} ; \mathrm{N} 3=134 \mathrm{~kg} \mathrm{ha}^{-1} ; \mathrm{N} 4=268 \mathrm{~kg} \mathrm{ha}^{-1}$. 


\section{CONCLUSIONS}

1. Biomass accumulation is more affected by nitrogen than by potassium fertilization;

2. There is an interaction between nitrogen and potassium doses for net photosynthesis, stomatal conductance, transpiration and instantaneous carboxylation, and the highest values are found with $125-185 \mathrm{~kg} \mathrm{ha}^{-1}$ of $\mathrm{K}$ and $268 \mathrm{~kg} \mathrm{ha}^{-1}$ of $\mathrm{N}$;

3 . The internal concentration of $\mathrm{CO}_{2}$ is significantly affected by potassium doses, while the water-use efficiency is affected by nitrogen doses.

\section{REFERENCES}

AMINIFARD, M. H. et al. Responses of eggplant (Solanum melongena L.) to different rates of nitrogen under field conditions. Journal of Central European Agriculture, v. 11, n. 4, p. 453-458, 2010.

ANDRADE JUNIOR, W. P. et al. Efeito do nitrato de potássio na redução do estresse salino no meloeiro. Revista Caatinga, v. 24, n. 3, p. 110-119, 2011.

BHUVANESWARI, G. et al. Application of nitrogen fertilizer on plant density, growth, yield and fruit of bell peppers (Capsicum annuum L.). International Letters of Natural Sciences, v. 8, n. 2, p. 81-90, 2014.

BILIBIO, C. et al. Função de produção da berinjela irrigada em ambiente protegido. Irriga, v. 15, n. 1, p. 10-22, 2010.

BOSCO, M. R. O. et al. Efeito do $\mathrm{NaCl}$ sobre o crescimento, fotossíntese e relações hídricas de plantas de berinjela. Revista Ceres, v. 56, n. 3, p. 296-302, 2009.

CASAROLI, D.; LIER, Q. J. V. Critérios para determinação da capacidade de vaso. Revista Brasileira de Ciência do Solo, v. 7, n. 1, p. 59-66, 2008.

CRUZ, J. L. et al. Níveis de nitrogênio e a taxa fotossintética do mamoeiro 'Golden'. Ciência Rural, v. 37, n. 1, p. 64-71, 2007.

EMPRESA BRASILEIRA DE PESQUISA AGROPECUÁRIA (Embrapa). Centro Nacional de Pesquisas de Solos. Sistema brasileiro de classificação de solos. Rio de Janeiro: Embrapa, 2013.

EVANS, J. R. Nitrogen and photosynthesis in the flag leaf of wheat (Triticum aestivum L.). Plant Physiology, v. 72, n. 1, p. 297-302, 1983.

FAQUIN, V.; ANDRADE, A. T. Nutrição mineral e diagnose do estado nutricional das hortaliças. 2004. $88 \mathrm{f}$. Especialização (Produção de Hortaliças) - Universidade Federal de Lavras, Lavras, 2004.
FAWZY, Z. et al. Influence of levels and methods of potassium fertilizer application on growth and yield of eggplant. Journal of Applied Sciences Research, v. 3, n. 1, p. 42-49, 2007.

FELSEMBURGH, C. A. Nitrogênio total em folhas e sua relação com o incremento em biomassa de florestas primária e manejada na Amazônia Central. 2006. $56 \mathrm{f}$. Dissertação (Mestrado em Biologia Tropical e Recursos Naturais) - Instituto Nacional de Pesquisas da Amazônia e Universidade Federal do Amazonas, Manaus, 2006.

HAFSI, C. et al. Antioxidative response of Hordeum maritimum L. to potassium deficiency. Acta Physiol Plant, v. 33, n. 1, p. 193-202, 2011.

HAFSI, C. et al. Effects of potassium supply on growth, gas exchange, phenolic composition, and related antioxidant properties in the forage legume Sulla carnosa. Flora, v. 223, n. 1, p. 38-45, 2016.

HOCHMUTH, G. J. et al. Eggplant yield in response to potassium fertilization on sandy soil. HortScience, v. 28, n. 10, p. 1002-1005, 1993.

INNOCENTI, E. D. et al. The effect of salinity on photosynthetic activity in potassium-deficient barley species. Journal of Plant Physiology, v. 166, n. 1, p. 19681981, 2009.

KERBAUY, G. B. Fisiologia vegetal. Rio de Janeiro: Guanabara Koogan, 2008.

LIEBIG, J. Die organische Chemie in ihrer Anwendung auf Agricultur und Physiologie (Organic chemistry in its applications to agriculture and physiology). Braunschweig: Friedrich Vieweg und Sohn, 1840.

LOPES, A. S. Manual internacional de fertilidade do solo. Piracicaba: Instituto da Potassa e Fosfato, 1998.

LORENZONI, M. Z. et al. Response of bell pepper crop fertigated with nitrogen and potassium doses in protected environment. Agrotechnology, v. 5, n. 2, p. 1-5, 2016.

MA, Q. et al. The dynamics of potassium uptake and use, leaf gas exchange and root growth throughout plant phenological development and its effects on seed yield in wheat (Triticum aestivum) on a low-K sandy soil. Plant Soil, v. 373, n. 1, p. 373-384, 2013.

MELO, A. S. et al. Alterações das características fisiológicas da bananeira sob condições de fertirrigação. Ciência Rural, v. 39, n. 3, p. 733-741, 2009.

PEEL, M. C. et al. Updated world map of the KöppenGeiger climate classification. Hydrology and Earth System Sciences, v. 11, n. 1, p. 1633-1644, 2007.

PIMENTEL, C. Metabolismo de carbono na agricultura tropical. Seropédica: Edur, 1998. 
PRAZERES, S. S. et al. Crescimento e trocas gasosas de plantas de feijão-caupi sob irrigação salina e doses de potássio. Revista Agroambiente On-Line, v. 9, n. 2, p. 111-118, 2015.

RIBEIRO, C. S. C. Berinjela (Solanum melongena L.). Brasília, DF: Embrapa Hortaliças, 2007.

RIPULLONE, F. et al. Variation in nitrogen supply changes water-use efficiency of Pseudotsuga menziesii and Populus x euroamericana: a comparison of three approaches to determine water-use efficiency. Tree Physiology, v. 24, n. 1, p. 671-679, 2004.

SEEMANN, J. R. et al. Environmental effects on photosynthesis, nitrogen-use efficiency, and metabolite pools in leaves of sun and shade plants. Plant Physiology, v. 84, n. 1, p. 796-802, 1987.

SILVA, F. G. et al. Trocas gasosas e fluorescência da clorofila em plantas de berinjela sob lâminas de irrigação.
Revista Brasileira de Engenharia Agrícola e Ambiental, v. 19, n. 10, p. 946-952, 2015.

SOUZA, A. H. C. et al. Response of eggplant crop fertigated with doses of nitrogen and potassium. Revista Brasileira de Engenharia Agrícola e Ambiental, v. 21, n. 1, p. 21-26, 2017.

TAIZ, L.; ZEIGER, E. Fisiologia vegetal. Porto Alegre: Artmed, 2013.

TRANI, P. E. Calagem e adubação para hortaliças sob cultivo protegido. Campinas: Instituto Agronômico, 2014.

TRANI, P. E. et al. Fertirrigação em hortaliças. Campinas: Instituto Agronômico, 2011. (Boletim técnico, 196).

XU, H. L. et al. Photosynthetic responses of greenhouse tomato plants to high solution electrical conductivity and low soil water content. Journal of Horticultural Science, v. 69, n. 5 , p. $821-832,1994$. 